\title{
PERAN DEWAN PENGAWAS SYARIAH DALAM PEMENUHAN PRINSIP SYARIAH DALAM PELAKSANAAN GOOD CORPORATE GOVERNANCE PADA PERBANKAN SYARIAH
}

\author{
Orisa Satifa \\ (Alumni STEI SEBI) \\ $\&$ \\ Edy Suprapto \\ (Dosen STEI SEBI)
}

\begin{abstract}
This research is departing from the development of Islamic banking industry, which is growing rapidly. Moreover, the bank demanded to implement good corporate governance (GCG) in order to prevent any risk of islamic banking losses, both financial loss and reputation risk. The implementation of GCG in islamic banking industry have to meet the shariah compiance. Thus, to ensure the shariah compliance, it requires shariah supervisiory board (DPS), which it serves to maintain the bank's adherence to islamic principles in their activities to manage customer funds. The regulation of Bank of Indonesia no. 11/33/PBI/2009 on the implementation of GCG in islamic banks provide a comprehensive policy regarding the duties and the responsibilities of the DPS to ensure the fulfillment of islamic principles in implementation of good corporate governance in islamic banking.
\end{abstract}

Keywords: Good corporate governance, Islamic Banking, Shariah Supervisiory Board, Shariah Principles, Regulation of Bank of Indonesia.

\section{PENDAHULUAN}

Industri perbankan syariah di Indonesia terus mengalami perkembangan. Besarnya jumlah masyarakat muslim di negara republik ini pada hakikatnya merupakan potensi besar bagi perbankan syariah untuk tumbuh dan berkembang. Statistik terakhir yang dilakukan BPS pada tahun 2010, jumlah keseluruhan penduduk Indonesia adalah 237.641.326 jiwa yang sebagian besarnya tertumpu di pulau Jawa. Dari keseluruhan jumlah tersebut sekitar 207.176.162 juta jiwa atau 87,18\% dari total penduduk Indonesia adalah muslim. (Badan Pusat Statistik, 
2010). Berdasarkan jumlah ini, Indonesia dikatakan sebagai negara yang berpenduduk muslim terbesar di dunia.

Dari segi institusi, perkembangan perbankan syariah di Indonesia bermula pada tahun 1991 dengan didirikannya Bank Muamalat Indonesia (BMI) yang mulai resmi beroperasi pada tahun 1992. Menurut Rae (2008), perkembangan perbankan syariah yang pesat baru terjadi setelah tahun 1998. (Sari, Bahari, \& Hamat, 2013, hal. 123). Perbankan syariah semakin mendapat perhatian setelah krisis yang mengakibatkan dilikuidasinya 16 bank oleh Bank Indonesia pada tanggal 1 November 1998. Krisis ini terjadi tidak lepas dari pengaruh lemahnya penerapan GCG. Skenario ini telah membuka ruang penerimaan yang lebih baik terhadap keuangan islam umumnya dan perbankan syariah khususnya. (Rochman, 2008)

Pada tahun 1992, hanya terdapat 1 bank umum syariah (BUS) yaitu bank Muamalat Indonesia dan 9 BPR Syariah (BPRS). Di tahun 1999, berdiri BUS kedua yaitu Bank Syariah Mandiri dan Unit Usaha Syariah (UUS) yang pertama yaitu UUS Bank IFI, dan jumlah BPRS melonjak mencapi 78. Di tahun 2004, berdiri BUS ketiga yaitu bank syariah Mega Indonesia dan jumlah UUS dan BPRS melonjak berturut-turut menjadi 15 dan 86. (Amin, 2007, hal. 56).

Dan kini, per Desember 2013, Berdasarkan data yang di keluarkan oleh Bank Indonesia terdapat peningkatan jumlah BUS, UUS dan BPRS yang juga telah diikuti oleh perkembangan jaringan kantor. Tercatat pada bulan Desember 2013, jumlah BUS adalah sebanyak 11 perusahaan, sedangkan jumlah UUS sebanyak 23, dan BPRS sebanyak 163 perusahaan.

Tabel I. 1 Jaringan Kantor Perbankan Syariah

\begin{tabular}{|l|l|l|l|l|l|l|l|}
\hline & $\mathbf{2 0 0 7}$ & $\mathbf{2 0 0 8}$ & $\mathbf{2 0 0 9}$ & $\mathbf{2 0 1 0}$ & $\mathbf{2 0 1 1}$ & $\mathbf{2 0 1 2}$ & $\mathbf{2 0 1 3}$ \\
\hline $\begin{array}{l}\text { Bank Umum } \\
\text { Syariah }\end{array}$ & & & & & & & \\
\hline $\begin{array}{l}\text { - Jumlah } \\
\text { Bank }\end{array}$ & 3 & 5 & 6 & 11 & 11 & 11 & 11 \\
\hline $\begin{array}{l}\text { Jumlah } \\
\text { Kantor }\end{array}$ & 401 & 581 & 711 & $\begin{array}{l}1,21 \\
5\end{array}$ & $\begin{array}{l}1,40 \\
1\end{array}$ & $\begin{array}{l}1,74 \\
5\end{array}$ & $\begin{array}{l}1,99 \\
8\end{array}$ \\
\hline $\begin{array}{l}\text { Unit Usaha } \\
\text { Syariah }\end{array}$ & & & & & & & \\
\hline $\begin{array}{l}\text { - JumlahBan } \\
\text { k }\end{array}$ & 26 & 27 & 25 & 23 & 24 & 24 & 23 \\
\hline $\begin{array}{l}\text { Jumlah } \\
\text { Kantor }\end{array}$ & 196 & 241 & 287 & 262 & 336 & 517 & 590 \\
\hline
\end{tabular}




\begin{tabular}{|l|l|l|l|l|l|l|l|}
\hline BPRS & & & & & & & \\
\hline $\begin{array}{l}\text { - Jumlah } \\
\text { Bank }\end{array}$ & 114 & 131 & 138 & 150 & 155 & 158 & 163 \\
\hline $\begin{array}{l}\text { - Jumlah } \\
\text { Kantor }\end{array}$ & 185 & 202 & 225 & 286 & 364 & 401 & 402 \\
\hline Total Kantor & 782 & $\begin{array}{l}1,02 \\
4\end{array}$ & $\begin{array}{l}1,22 \\
3\end{array}$ & $\begin{array}{l}1,76 \\
3\end{array}$ & $\begin{array}{l}2,10 \\
1\end{array}$ & $\begin{array}{l}2,66 \\
3\end{array}$ & $\begin{array}{l}2,99 \\
0\end{array}$ \\
\hline
\end{tabular}

Sumber: (Direktorat Perbankan Syariah, 2013)

Selama kurun waktu 4 (empat) tahun terakhir (2010-2013), dalam hal pencapaian aset perbankan syariah juga mengalami peningkatan, pada bulan Desember 2013 total aset perbankan syariah mencapai Rp 242,2 triliun. Jumlah ini mengalami peningkatan dari 3 (tiga) tahun sebelumnya yang pencapaian asetnya berurut dari tahun 2010 adalah 97,5 triliun, 145,4 triliun, 195 triliun.

Gambar I. 1 Pencapaian Aset Perbankan Syariah

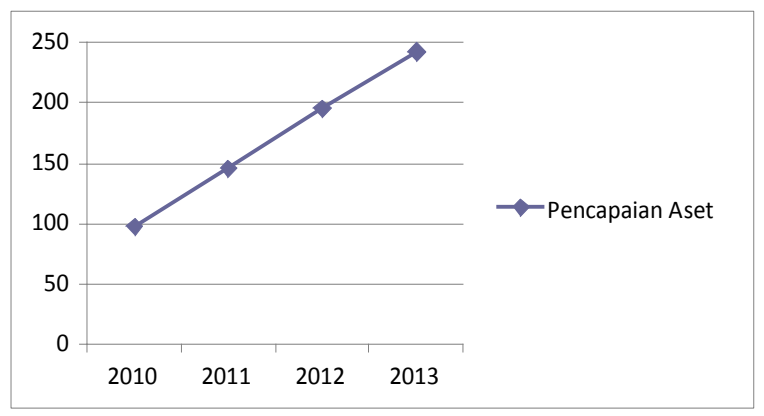

Sumber: (Direktorat Perbankan Syariah, 2013)

Dari beberapa faktor yang telah disebutkan sebelumnya, yaitu krisis tahun 1998 yang terjadi akibat lemahnya corporate governance, kondisi industri perbankan syariah saat ini yang semakin berkembang, yang ditandai dengan banyaknya bank yang beroperasi secara syariah dan memiliki lebih dari 500 kantor cabang, pertumbuhan aset yang terus meningkat, dan semakin beragamnya produk jasa keuangan yang ditawarkan, menyebabkan penerapan good corporate governance (GCG) pada perbankan syariah menjadi semakin penting. GCG berfungsi untuk mengantisipasi berbagai macam resiko, baik resiko finansial maupun reputasi, juga merupakan pilar penting yang harus diterapkan untuk mewujudkan bank syariah yang tangguh dan unggul. (Agustianto, 2011) 
Bank merupakan lembaga yang eksistensinya membutuhkan kepercayaan dari masyarakat. (Umam, 2012, hal. 358). Aspek kesesuaian dengan syariah merupakan aspek utama dan mendasar yang membedakan antara bank syariah dengan bank konvensional. Tuntutan pemenuhan prinsip syariah (shariah compliance), bila dirujuk pada sejarah perkembangan bank syariah, alasan pokok dari keberadaan perbankan syariah adalah munculnya kesadaran masyarakat muslim yang ingin menjalankan seluruh aktivitas keuangannya berdasarkan al qur'an dan sunnah. Oleh karena itu jaminan terhadap pemenuhan prinsip syariah (shariah compliance) dari seluruh aktivitas pengelolaan dana nasabah oleh bank syariah merupakan hal yang sangat penting dalam kegiatan usaha bank syariah. Karena berdasarkan hasil penelitian Chapra dan Ahmed (2002) juga menandaskan hal ini, dimana sejumlah 288 nasabah (62\%) responden dari 463 nasabah yang terlibat dalam survei tata kelola (GCG) yang dilakukannya (berasal dari 14 bank syariah di Bahrain, Bangladesh dan Sudan) menjawab akan memindahkan dananya ke bank syariah yang lain jika ditengarai terjadi "pelanggaran syariah" dalam operasional bank syariah. (Wardayati, 2011, hal. 8).

Oleh karena itu, dalam rangka meningkatkan kepercayaan masyarakat terhadap bank syariah diperlukan adanya pelaksanaan prinsip tata kelola perusahaan yang baik atau yang lebih dikenal dengan prinsip good corporate governance (GCG). GCG merupakan suatu sistem pengelolaan perbankan yang dirancang untuk meningkatkan kinerja bank, melindungi stakeholders dan meningkatkan kepatuhan terhadap perundang-undangan serta nilai-nilai etika yang berlaku secara umum. (Susanto, 2008, hal. 127). Oleh sebab itu, untuk membangun kepercayaan masyarakat kepada bank syariah dan menjamin kepatuhan terhadap prinsip syariah, diperlukan penerapan GCG sebagai syarat bagi bank syariah untuk berkembang dengan baik dan sehat.

Agar pelaksanaan GCG lebih efektif di perbankan syariah, Bank Indonesia telah mengeluarkan Peraturan Bank Indonesia No. 11/33/PBI/2009 tentang pelaksanaan good corporate governance (GCG) bagi bank umum syariah dan unit usaha syariah pada tanggal 29 Januari 2009 yang selanjutnya dilengkapi dengan Surat Edaran Bank Indonesia No. 12/13/Dpbs tanggal 30 April 2010 perihal pelaksanaan GCG pada bank umum syariah dan unit usaha syariah. Peraturan ini melengkapi pengaturan pelaksanaan tata kelola perusahaan yang baik bagi perbankan syariah berdasarkan undang-undang No. 21 tahun 2008 tentang perbankan syariah. 
Pelaksanaan good corporate governance (GCG) pada perbankan syariah berdasarkan PBI No. 11/33/PBI/2009 harus berlandaskan pada prinsip keterbukaan (transparancy), akuntabilitas (accontability), pertanggungjawaban (responsibility), profesional (professional) dan kewajaran (fairness). Selain itu, pelaksanaan GCG di bank syariah juga harus memenuhi kepatuhan terhadap prinsip syariah (sharia compliance). Penerapan GCG di bank syariah tidak bisa dipisahkan dari kewajibannya untuk menjalankan kegiatan usaha yang berlandaskan prinsip syariah. Hal inilah yang membedakan penerapan GCG pada perbankan syariah, yaitu adanya kewajiban terhadap pemenuhan prinsip syariah, sedangkan prinsip-prinsip transparansi, independensi, kejujuran, disiplin dan profesional merupakan prinsip universal yang juga terdapat dalam aturan GCG konvensional.

Berdasarkan penelitian yang dilakukan Siti Maria Wardayati (2011), untuk mengetahui tanggapan responden terhadap penerapan good corporate governance pada bank Muamalat dengan menggunakan 6 (enam) indikator: transparancy, accountability, responsibility, independency, fairnes dan shariah compliance, menunjukkan hasil bahwa shariah compiance merupakan indikator yang paling berpengaruh, sehingga dalam penerapan GCG di perbankan syariah, para pengelola bank syariah harus benar-benar merujuk kepada kepatuhan terhadap prinsip-prinsip dan nilai-nilai syariah, karena perbankan syariah merupakan lembaga intermediasi yang amat membutuhkan kepercayaan masyarakat agar dipercaya seluruh stakeholders. Disinilah pentingnya peranan dewan pengawas syariah (DPS) dalam menjaga pemenuhan prinsip syariah yang berkaitan erat dengan pengelolaan perusahaan dari sisi kebenaran syariah, dan hal ini akan menjadi sangat penting ketika perusahaan akan mengeluarkan produk-produk perbankannya. Sehingga, bisa disimpulkan bahwa selain tata kelola yang baik dari sisi manajemen perusahaan, tata kelola pengawasan dan pengembangan yang dilakukan oleh DPS menjadi tolak ukur mendasar dalam kesuksesan penerapan GCG di perbankan syariah.

Untuk menjalankan perannya, DPS harus memiliki kualifikasi keilmuan yang integral, yaitu ilmu fiqih muamalah dan ilmu ekonomi keuangan islam modern (Madjid, 2011, hal. 5), bukan karena kharisma dan kepopulerannya ditengah masyarakat. Jika pengangkatan DPS bukan didasarkan pada keilmuannya, maka fungsi pengawasan DPS tidak akan efektif sehingga dapat menyebabkan terjadinya penyimpangan praktek syariah. Oleh karenanya, tidak heran jika masih ditemukan pelanggaran aspek syariah yang dilakukan oleh lembaga-lembaga perbankan syariah, 
khususnya perbankan yang konversi ke syariah atau membuka unit usaha syariah. Yang juga mengherankan lagi adalah, seringkali kasus-kasus yang menyimpang dari syariah islam di bank syariah lebih dahulu diketahui oleh Bank Indonesia daripada oleh DPS, Sebagaimana yang pernah terjadi pada tahun 2012 dimana Bank Indonesia menemukan pelanggaran prosedur gadai emas pada bank syariah sehingga harus dibekukan untuk sementara waktu. (Santoso, 2012).

Pelanggaran kepatuhan syariah yang dibiarkan DPS atau luput dari pengawasan DPS, jelas akan merusak citra dan kredibilitas bank syariah di mata masyarakat, sehingga dapat menurunkan kepercayaan masyarakat kepada bank syariah. (Wardayati, 2011, hal. 18). Untuk itulah peran penting DPS dalam pelaksanaan GCG di bank syariah harus benar-benar dioptimalkan, dengan cara memberikan garis panduan mengenai tugas dan tanggung jawab DPS yang sesuai dengan prinsip-prinsip pelaksanaan GCG di perbankan syariah.

\section{TINJAUAN PUSTAKA}

\subsection{Pengertian Bank Syariah}

Bank syariah adalah suatu lembaga keuangan yang berfungsi sebagai perantara bagi pihak yang berkelebihan dana dengan pihak yang kekurangan dana untuk kegiatan usaha dan kegiatan lainnya sesuai dengan hukum islam. (Ali, 2007, hal. 1).

Dalam Undang-undang No. 21 tahun 2008 tentang perbankan syariah disebutkan bahwa bank syariah adalah bank yang menjalankan kegiatan usahanya berdasarkan prinsip syariah. Sedangkan yang dimaksud dengan prinsip syariah (masih berdasarkan undang-undang No. 21 tahun 2008) adalah prinsip hukum islam dalam kegiatan perbankan syariah berdasarkan fatwa yang di keluarkan oleh lembaga yang memiliki kewenangan dalam penetapan fatwa dibidang syariah.

\subsection{Dasar Pemikiran Terbentuknya Bank Syariah}

Dasar pemikiran terbentuknya perbankan syariah adalah adanya larangan riba di dalam Al Quran dan Hadits. Riba adalah pengambilan tambahan, baik dalam transaksi jual beli maupun pinjam meminjam secara bathil atau bertentangan dengan prinsip muamalah dalam isalm. (Antonio, 2001, hal. 37). Ayat Al Qur'an yang menjelaskan tentang larangan riba terdapat dalam surat Al Baqarah ayat 275, sebagaimana berikut ini:

"orang-orang yang memakan riba tidak akan berdiri melainkan seperti berdirinya orang yang kemasukan setan karena gila. Yang demikian itu karena mereka mengatakan 
bahwa: "Jual beli sama dengan riba." Padahal Allah telah menghalalkan jual beli dan mengharamkan riba. Barangsiapa mendapatkan peringatan dari tuhannya, lalu ia berhenti (dari memakan riba), maka apa yang telah diperolehnya dahulu menjadi miliknya dan urusanya (terserah) kepada Allah. Barang siapa mengulangi, maka mereka itu penghuni neraka, mereka kekal di dalamnya." (Al-Baqarah : 275).

Banyak hadits-hadits yang terkait dengan larangan riba. Berikut ini adalah salah satu dari pelarangan riba dalam hadits:

Jabir berkata bahwa Rasulullah saw. Mengutuk orang yang menerima riba, orang yang membayarnya, dan orang yang mencatatnya, dan dua orang saksinya, kemudian beliau bersabda, "Mereka itu semuanya sama." (HR Muslim no. 2995, kitab al-Masaqqah).

\subsection{Dasar Hukum Perbankan Syariah Di Indonesia}

Undang-undang No. 7 tahun 1992 tentang perbankan merupakan tonggak lahirnya bank berdasarkan prinsip syariah. pasal 13 huruf c, undang-undang tersebut membuka kemungkinan bagi bank untuk melakukan kegiatan berdasarkan prinsip bagi hasil dengan nasabahnya. Kegiatan pembiayaan bagi hasil tersebut kemudian oleh undang-undang No 10 tahun 1998 tentang perubahan atas undang-undang No. 7 tahun 1992 tentang perbankan diperluas menjadi kegiatan apapun dari bank berdasarkan prinsip syariah yang ditetapkan oleh Bank Indonesia.

Seiring berjalannya waktu dan karena dianggap penting, maka terbitlah undang-undang nomor 21 tahun 2008 tentang perbankan syariah. Dalam undang-undang ini diatur secara lebih rinci mengenai bank syariah berikut hal-hal yang berkaitan dengan kegiatan perbankan syariah.

\subsection{Prinsip Dasar Operasional Bank Syariah}

Secara garis besar aktivitas bank berdasarkan syariah islam ditentukan oleh hubungan akad yang terdiri dari 5 (lima) konsep dasar akad. (Muhammad, 2011, hal. 13). Bersumber dari kelima konsep dasar inilah dapat ditemukan produk-produk lembaga keuangan bank syariah untuk dioperasionalkan. Kelima konsep tersebut adalah:

1. Prinsip simpanan murni (al wadi'ah)

Fasilitas al wadiah biasa diberikan untuk tujuan investasi guna mendapatkan keuntungan sepertihalnya tabungan dan deposito. Dalam dunia perbankan al waidah identik dengan giro.

2. Bagi hasil (Syirkah) 
Sistem ini adalah suatu sistem yang meliputi tata cara pembagian hasil usaha antara penyedia dana dengan pengelola dana. Bentuk produk berdasarkan prinsip ini adalah mudharabah dan musyarakah.

3. Prinsip jual beli (at Tijarah)

Prinsip ini merupakan suatu sistem yang menerapkan tata cara jual beli, dimana bank mengangkat nasabah sebagai agent bank untuk melakukan pembelian barang atas nama bank, kemudian bank menjual barang tersebut kepada nasabah dengan harga sejumlah harga beli ditambah keuntungan (margin).

4. Prinsip sewa (al Ijarah)

Prinsip ini secara garis besar terbagi menjadi dua jenis: (i) Ijarah, sewa murni (operating lease) dan (ii) bai al takjiri atau ijarah al muntahiya bit tamlik merupakan penggabungan sewa dan beli (financial lease).

5. Prinsip fee/ jasa (al Ajr wal umullah)

Prinsip ini meliputi seluruh layanan non-pembiayaan yang diberikan bank. Bentuk produk yang berdasarkan prinsip ini antara lain bank garansi, kliring, inkaso dan jasa transfer.

\subsection{Good Corporate Governance (GCG) Pada Perbankan Syariah}

Sebagaimana perbankan konvensional, perbankan syariah dalam pengoperasiannya juga mempunyai kebutuhan untuk menerapkan prinsipprinsip GCG, dikarenakan situasi eksternal dan internal perbankan syariah yang semakin kompleks juga disertai dengan semakin beragamnya tingkat resiko kegiatan perbankan syariah. Setelah berlakunya undang-undang No. 21 tahun 2008 tentang perbankan syariah, ketentuan mengenai tata kelola perusahaan yang baik yang identik dengan GCG juga dicantumkan secara singkat. Dalam undang-undang No. 21 tahun 2008 pasal 34, dinyatakan bahwa bank syariah dan unit usaha syariah wajib menerapkan tata kelola yang baik yang mencakup prinsip transparansi, akuntabilitas, pertanggungjawaban, profesional dan kewajaran dalam menjalankan kegiatan usahanya. Pengaturan ini kemudian dilengkapi dengan di keluarkannya Peraturan Bank Indonesia No. 11/33/PBI/2009 tentang pelaksanaan GCG bagi bank umum syariah dan unit usaha syariah pada tanggal 29 Januari 2009.

Dalam PBI No. 11/33/PBI/2009 pasal 1 angka 10, disebutkan bahwa GCG adalah suatu tata kelola bank yang menerapkan prinsipprinsip keterbukaan (transparency), akuntabilitas (accountability), pertanggungjawaban (responsibility), profesional (professional), dan kewajaran (fairnes). Namun dalam pertimbangannya, PBI menyatakan 
bahwa pelaksanaan GCG pada perbankan syariah harus memenuhi prinsip syariah (sharia compliance). Hal inilah yang merupakan salah satu yang membedakan penerapan GCG pada perbankan konvensional dengan perbankan syariah.

\subsection{Pengertian Good Corporate Governance (GCG)}

Terdapat berbagai definisi yang dikemukakan oleh para ahli maupun lembaga-lembaga yang concern pada bidang corporate governance, sehingga tidak terdapat satu definisi tunggal yang berterima. Bank Dunia (World Bank) mendefinisikan corporate governance sebagai kumpulan hukum, peraturan dan kaidah-kaidah yang wajib dipenuhi yang dapat mendorong kinerja sumber-sumber perusahaan bekerja secara efisien, menghasilkan nilai ekonomi jangka panjang yang berkesinambungan bagi para pemegang saham maupun masyrakat sekitar secara keseluruhan.

Sementara menurut Forum For Corporates Governance In Indonesia (FCGI) corporate governance adalah seperangkat peraturan yang menetapkan hubungan antara pemegang saham, pengurus, pihak kreditur, pemerintah, karyawan serta para pemegang kepentingan internal dan eksternal lainnya sehubungan dengan hak-hak dan kewajiban mereka atau dengan kata lain sistem yang mengerahkan dan mengendalikan perusahaan. (Tunggal A. W., 2007, hal. 1)

Dari beberapa definisi yang dikemukakan di atas dapat disimpulkan bahwa corporate governance adalah suatu sistem yang dibangun untuk mengarahkan dan mengendalikan perusahaan sehingga tercipta tata hubungan yang baik, adil, dan transparan diantara berbagai pihak yang terkait dan memiliki kepentingan (stakeholders) dalam perusahaan.

\subsection{Prinsip-Prinsip Good Corporate Governance (GCG)}

Pelaksanaan GCG pada perbankan syariah memerlukan adanya pemahaman mengenai prinsip-prinsip GCG. Dalam PBI No. 11/33/PBI/2009 disebutkan bahwa ada 5 (lima) prinsip dasar terkait dengan GCG, yaitu:

1. Transparansi (Tranparancy) yang berarti tersedianya informasi yang akurat, relevan dan mudah dimengerti sehingga stakeholders dapat memberi keputusan.

2. Akuntabilitas (Accountability) yang berarti manajemen harus mampu merespon pertanyaan dari stakeholders mengenai pertanggung jawaban pelaksanaan manajemen perusahaan. 
3. Pertanggungjawaban (Responbility) yaitu perusahaan mampu dikelola sesuai dengan hukum dan peraturan perundangundangan yang berlaku.

4. Indepedensi (Independency) yang berarti tindakan hanya dilakukan untuk kepentingan perusahaan tanpa ada pengaruh dari pihak lain untuk menghindari conflict of interest.

5. Kewajaran (Fairnes) yang berarti adanya perlindungan terhadap hak-hak stakeholders.

Dalam ajaran islam, kelima prinsip-prinsip pokok diatas sesuai dengan norma dan nilai islami dalam aktivitas dan kehidupan seorang muslim. Islam sangat intens mengajarkan diterapkannya prinsip 'adalah (keadilan), tawazun (keseimbangan), mas'uliyah (akuntabilitas), akhlaq (moral), shiddiq (kejujuran), amanah (pemenuhan kepercayaan), fathanah (kecerdasan), tabligh (transparansi), hurriyah (independensi dan kebebasan yang bertanggung jawab), ihsan (profesional), wasathan (kewajaran), ghirah (pengelolaan syariah), khilafah (kepemimpinan), aqidah (keimanan), ijabiyah (berpikir positif), raqabah (pengawasan), qira'ah dan islah (organisasi yang selalu melakukan perbaikan). Jadi pada dasarnya, konsep Good Corporate Governance (GCG) yang harus diterapkan dalam perbankan syariah sesuai dengan konsep dan norma islam dalam hukum islam. (Wardayati, 2011, hal. 9).

\subsection{Dewan Pengawas Syariah (DPS) Di Perbankan Syariah}

Salah satu perbedaan yang mendasar dalam struktur organisasi perbankan konvensional dengan perbankan syariah adalah adanya kewajiban memposisikan dewan pengawas syariah (DPS) dalam perbankan syariah. DPS adalah lembaga independen atau juris khusus dalam bidang fiqih muamalah. Namun DPS juga bisa beranggotakan di luar ahli fiqih tetapi harus memiliki keahlian dalam bidang lembaga keuangan islam dan fiqih muamalah. (Faozan, 2013, hal. 10).

Dalam undang-undang No. 10 tahun 1998 tentang perubahan undang-undang No. 7 tahun 1992 tentang perbakan, dinyatakan bahwa dalam suatu perbankan islam harus dibentuk DPS. Begitu juga dalam undang-undang No. 21 tahun 2008 tentang perbankan syariah pasal 32 angka 1 menyatakan bahwa DPS wajib dibentuk di bank syariah dan bank konvensional yang memiliki unit usaha syariah.

DPS dalam struktur organisasi bank diletakkan pada posisi setingkat dengan dewan komisaris pada setiap bank syariah. Posisi yang demikian ditujukan agar DPS lebih berwibawa dan mempunyai kebebasan opini dalam memberikan bimbingan dan pengarahan kepada 
semua direksi di bank tersebut dalam hal-hal yang berhubungan dengan pengaplikasian produk perbankan syariah, oleh sebab itu, penetapan DPS dilakukan melalui rapat umum pemegang saham (RUPS) setelah namanama anggota DPS tersebut mendapat pengesahan dari DSN. (Rachmat, 2013, hal. 4).

Ketentuan mengenai jumlah anggota DPS juga diatur dalam PBI No. 11/3/PBI/2009 tentang bank umum syariah yang menyatakan bahwa jumlah anggota DPS paling sedikit adalah 2 (dua) orang dan paling banyak adalah 50\% dari jumlah anggota direksi. DPS diketuai oleh salah satu dari anggota DPS bank yang bersangkutan. PBI No. 11/3/PBI/2009 memberikan aturan bahwa anggota DPS dapat merangkap jabatan di 4 (empat) lembaga keuangan syariah. Ini menjadikan ketentuan mengenai DPS di bank syariah menjadi lebih fleksibel.

\section{METODOLOGI PENELITIAN}

\subsection{Jenis Penelitian}

Penyusunan studi mandiri ini dilakukan dengan menggunakan metode penelitian hukum normatif yang bersifat deskriptif. Penelitian hukum normatif yaitu pendekatan dengan meninjau masalah yang diteliti dari segi ilmu hukum dan dengan melakukan analisis terhadap normanorma hukum yang berlaku dalam peraturan perundang-undangan berdasarkan bahan hukum primer, sekunder dan tersier untuk mendapatkan kesimpulan dari data-data yang diperoleh dalam penelitian. (Soekanto, 1990, hal. 118).

Sedangkan metode deskriptif dapat diartikan sebagai prosedur pemecahan masalah yang diselidiki dengan menggambarkan/ melukiskan keadaan subjek/objek penelitian (seseorang, lembaga, masyarakat, dan lain-lain) pada saat sekarang berdasarkan fakta-fakta atau sebagaimana adanya. (Soejono \& Abdurrahman, 2003, hal. 23).

Penelitian hukum normatif dapat juga disebut dengan penelitian hukum kepustakaan atau studi pustaka. Tujuan dan kegunaan studi kepustakaan pada dasarnya adalah menunjukkan jalan pemecahan permasalahan penelitian, bahkan dapat dikatakan bahwa studi kepustakaan merupakan separuh dari keseluruhan aktifitas penelitian itu sendiri, six hour in library save six mounth in field or laboratory. (Sunggono, 2010, hal. 112).

Suatu penelitian normatif tentu harus menggunakan pendekatan peraturan perundang-undangan, karena yang diteliti adalah berbagai aturan hukum yang menjadi fokus sekaligus tema sentral penelitian. (Ibrahim, 2005, hal. 248). Maka untuk mengadakan pembahasan terhadap 
masalah "Peran Dewan Pengawas Syariah Dalam Pemenuhan Prinsip Syariah Dalam Pelaksanaan Good Corporate Governance Pada Perbankan Syariah" dikaji dalam hukum islam dan hukum positif di Indonesia, pendapat ahli hukum dan ahli perbankan syariah sesuai dengan sifat penelitian hukum normatif.

\subsection{Sumber Data}

Di dalam penelitian hukum normatif, maka data yang digunakan adalah data sekunder yaitu data yang diperoleh dari bahan-bahan pustaka. Di dalam penelitian hukum, data sekunder mencakup:

a. Bahan hukum primer yaitu bahan hukum yang isinya memiliki kekuatan yang mengikat karena di keluarkan oleh pemerintah, dan terdiri dari undang-undang, peraturan bank indonesia, surat edaran bank indonesia.

b. Bahan hukum sekunder yaitu bahan hukum yang erat hubungannya dengan bahan hukum primer untuk membantu menganalisa dan memahami bahan hukum primer seperti bukubuku, artikel, jurnal dan media elektronik.

c. Bahan hukum tersier yaitu bahan hukum yang memberikan petunjuk dan sifatnya menunjang bahan hukum primer dan sekunder seperti kamus hukum dan kamus perbankan.

\subsection{Teknik Pengumpulan Data}

Pengumpulan data sekunder dilakukan dengan menggunakan studi dokumen/studi pustaka dari bahan-bahan pustaka, yaitu dengan mengumpulkan berbagai ketentuan peraturan perundang-undangan, bukubuku, jurnal, dan artikel yang berkaitan dengan judul studi mandiri ini.

Salah satu cara yang digunakan untuk melakukan studi dokumen adalah dengan melakukan analisa isi (content analysis). Content analysis adalah teknik untuk menganalisa tulisan atau dokumen dengan cara mengidentifikasi secara sistematik ciri atau karakter dan pesan atau maksud yang terkandung dalam tulisan atau suatu dokumen.

\section{PEMBAHASAN}

\subsection{Peran Dewan Pengawas Syariah Dalam Pemenuhan Prinsip} Syariah Dalam Pelaksanaan Good Corporate Governance Pada Perbankan Syariah

Setelah mengetahui bahwa dewan pengawas syariah (DPS) berperan penting dalam pelaksanaan good corporate governance (GCG ) di perbankan syariah, maka pada bagian ini akan dijelaskan dengan lebih 
rinci tentang bagaimana peran DPS dalam pemenuhan prinsip syariah dalam pelaksanaan GCG di perbankan syariah. Untuk itu, maka pembahasan mengenai masalah ini mengacu kepada Peraturan Bank Indonesia No. 11/33/PBI/2009 tentang pelaksanaan GCG pada bank umum syariah dan unit usaha syariah. PBI No. 11/33/PBI/2009 selain mengatur GCG secara mendasar, juga mengatur tentang pelaksanaan tugas dan tanggung jawab dewan pengawas syariah, karena adanya pelaksanaan tugas dan tanggung jawab DPS merupakan salah satu wujud dari pelaksanaan GCG di perbankan syariah.

Pasal 46 PBI No. 11/33/PBI/2009 menyebutkan bahwa dewan pengawas syariah (DPS) wajib melaksanakan tugas dan tanggung jawab sesuai dengan prinsip-prinsip GCG. Kemudian pada pasal 47 dijelaskan bahwa yang dimaksud dengan tugas dan tanggung jawab DPS adalah memberikan nasihat dan saran kepada direksi serta mengawasi kegiatan bank agar sesuai dengan prinsip syariah.

Pelaksanaan tugas dan tanggung jawab DPS dalam mendukung pelaksanaan GCG pada perbankan syariah, sebagaimana yang dimaksud dalam pasal 47, yakni memberi nasihat dan saran kepada direksi serta mengawasi kegiatan bank agar sesuai dengan prinsip syariah, meliputi hal-hal sebagai berikut:

a) Menilai dan memastikan pemenuhan prinsip syariah atas pedoman operasional dan produk yang di keluarkan bank.

b) Mengawasi proses pengembangan produk baru bank agar sesuai dengan fatwa DSN MUI.

c) Meminta fatwa kepada DSN MUI untuk produk baru bank yang belum ada fatwanya.

d) Melakukan review secara berkala atas pemenuhan prinsip syariah terhadap mekanisme penghimpunan dana dan penyaluran dana serta pelayanan jasa bank.

e) Meminta data informasi terkait dengan aspek syariah dari satuan kinerja bank dalam pelaksanaan tugasnya.

Selain itu, dewan pengawas syariah juga wajib menyampaikan laporan hasil pengawasannya secara semesteran kepada stakeholders. Seperti Otoritas Perbankan Syariah, Dewan Syariah Nasional Majelis Ulama Indonesia (DSN MUI), Komisaris, dan Direksi bank syariah. Tata cara pelaporannya diatur secara lebih rinci dalam Surat Edaran Bank Indonesia. Dewan pengawas syariah (DPS) juga wajib menyediakan waktu yang cukup untuk melaksanakan tugas dan tanggung jawabnya secara optimal. 
Dari penjelasan tersebut dapat ditarik kesimpulan bahwa DPS dalam melaksanakan tugas dan tanggung jawabnya terhadap pemenuhan prinsip syariah dalam pelaksanaan GCG di perbankan syariah memiliki 3 (tiga) fungsi, yaitu: dalam rangka menjalankan fungsi koordinasi, fungsi pengawasan dan fungsi pelaporan.

\subsection{Pelaksanaan Tugas Dan Tanggung Jawab DPS Dalam Rangka Koordinasi}

Fungsi koordinasi DPS dilakukan dengan cara melaksanakan seluruh proses komunikasi dalam rangka implementasi prinsip syariah dan pemenuhan prinsip syariah pada bank, yang meliputi:

1) Mengikuti rapat dan diskusi dengan pihak internal terkait pemenuhan prinsip syariah.

Rapat dengan pihak internal biasanya dilakukan DPS bersama direksi, bersama divisi, atau bersama unit kerja lainnya. Rapat DPS dilaksanakan untuk membahas persoalan-persoalan yang dihadapi oleh direksi, divisi, atau unit kerja lainnya yang terkait dengan rencana pengambilan kebijakan dan pelaksanaan operasional di bank syariah berdasarkan prinsip syariah.

DPS juga bisa memberikan pelayanan konsultasi syariah bagi direksi, divisi, atau unit kerja lainnya, baik yang bersifat formal maupun bersifat informal. Konsultasi syariah dapat dilakukan secara langsung maupun tidak langsung yang berkaitan dengan aspek-aspek syariah pada pelaksanaan kegiatan operasional bank syariah. Pelayanan konsultasi syariah diberikan oleh DPS setiap hari kerja agar bank syariah tetap konsisten dalam pemenuhan prinsip syariah. Konsultasi syariah yang dilakukan diklasifikasikan berdasarkan tingkat urgensi permasalahan, jika permasalahan yang disampaikan memerlukan opini syariah, maka DPS akan menyampaikan opini syariah terkait dengan permasalahan yang dihadapi untuk dijadikan sebagai pedoman syariah dalam menjalankan kegiatan operasional bank syariah. Selanjutnya, DPS juga turut serta dalam memberikan pelatihan pendidikan dasar bank syariah dan refreshment pengetahuan syariah untuk pegawai, dengan menjadi instruktur pelatihan baik oleh anggota DPS secara langsung atau melalui staf DPS.

2) Mewakili dan mendampingi bank syariah yang diawasinya untuk rapat, diskusi, dan konsultasi kepada pihak eksternal terkait pemenuhan prinsip syariah. 
DPS mendampingi divisi atau unit kerja dalam bank syariah yang bertanggung jawab dalam hal pengembangan produk atau pelayanan jasa untuk berkonsultasi dengan BPH DSN MUI mengenai akad yang akan atau dapat digunakan pada skema bisnis. Konsultasi dilakukan dengan metode presentasi dengan memaparkan skema bisnis, usulan akad, dan pokok persoalan yang dihadapi oleh bank syariah. Kemudian DSN MUI memberikan pandangan atau rekomendasi atas persoalan tersebut. Kegiatan DPS selanjutnya yang termask ke dalam bagian ini adalah menghadiri pertemuan tahunan (ijtima' sanawi) yang diselenggarakan oleh DSN MUI. DPS juga terlibat dalam kegiatan sosialisasi transaksi syariah kepada koperasi, BMT, atau entitas lainnya yang mengundang atau meminta, kepada DPS untuk memberikan penjelasan tentang implementasi akad-akad syariah pada lembaga keuangan.

\subsection{Pelaksanaan Tugas Dan Tanggung Jawab DPS Dalam Rangka Pengawasan}

Ada 3 (tiga) macam aktivitas Dewan Pengawas Syariah (DPS) dalam melaksanakan pengawasan syariah. (Sutedi, 2009, hal. 144), yaitu sebagai berikut:

a) Ex ante auditing

Aktivitas pengawasan syariah dengan melakukan pemeriksaan terhadap berbagai kebijakan moral yang diambil dengan cara melakukan review terhadap keputusan-keputusan manajemen dan melakukan review terhadap semua jenis kontrak yang dibuat manajemen bank syariah dengan semua pihak. Tujuannya adalah untuk mencegah bank syariah melakukan kontrak yang melanggar prinsip-prinsip syariah.

b) Ex post auditing

Aktivitas pengawasan syariah dengan melakukan pemeriksaan terhadap laporan kegiatan (aktivitas) dan laporan keuangan bank syariah. Tujuannya adalah untuk menelusuri kegiatan dan sumbersumber keuangan bank syariah yang tidak sesuai dengan prinsipprinsip syariah.

c) Perhitungan dan pembayaran zakat

Aktivitas pengawasan syariah dengan memeriksa kebenaran bank syariah dalam menghitung zakat yang harus dikeluarkan dan memeriksa kebenaran dalam pembayaran zakat sesuai dengan ketentuan syariah. Tujuannya adalah untuk memastikan agar zakat atas segala usaha yang berkaitan dengan hasil usaha bank syariah 
telah dihitung dan dibayar secara benar oleh manajemen bank syariah.

Berdasarkan hal tersebut dapat disimpulkan bahwa DPS mempunyai tugas dan tanggung jawab untuk menjalankan fungsi pengawasannya dengan mencakup kepada pengawasan terhadap pengembangan produk baru dan juga pengawasan terhadap kegiatan bank syariah, meliputi hal-hal berikut ini:

1) Menilai dan memastikan pemenuhan prinsip syariah atas pedoman operasional dan produk yang di keluarkan bank.

Tanggung jawab DPS atas jaminan pemenuhan prinsip syariah, tidak hanya terbatas pada produk jasa keuangan yang ada di bank syariah saja, lebih luas dari itu, DPS juga bertanggung jawab untuk memastikan bahwa kegiatan operasional dan aktivitas pengelolaan dana yang dilakukan bank syariah telah sesuai dengan aturan-aturan syariah berlaku.

Dalam pelaksanaanya memastikan pemenuhan prinsip syariah terhadap produk yang di keluarkan bank, maka DPS bertugas meneliti dan membuat rekomendasi produk baru bank syariah yang diawasinya. Dengan demikian, DPS bertindak sebagai penyaring pertama sebelum suatu produk diteliti kembali dan difatwakan oleh DSN. (Antonio, 2001, hal. 31). Selanjutnya, secara berkala DPS harus melakukan review terhadap produk baru yang akan di keluarkan terkait dengan aspek pemenuhan prinsip syariahnya, untuk kemudian hasil review tersebut disampaikan kepada pihak-pihak yang berkepentingan, yaitu Direksi, Dewan Komisaris dan OJK.

DPS bertugas mengawasi jalannya operasional bank sehari-hari agar selalu sesuai dengan ketentuan-ketentuan syariah. Hal ini karena transaksi-transaksi yang berlaku dalam bank syariah sangat khusus jika dibanding bank konvensional. Karena itu diperlukan garis panduan (guidelines) yang mengaturnya. Garis panduan ini disusun dan ditentukan DSN. (Antonio, 2001, hal. 31). DPS juga harus melakukan review terhadap standar operasional prosedur (SOP) terkait aspek syariah apabila terdapat indikasi ketidaksesuaian pelaksanaan pemenuhan prinsip syariah atas kegiatan yang dimaksud.

2) Mengawasi proses pengembangan produk baru bank agar sesuai dengan fatwa DSN MUI.

Seperti halnya bank konvensional, perkembangan usaha bank syariah juga tergantung antara lain dari kemampuannya untuk tetap dapat mengakomodasi kebutuhan masyarakat akan pelayanan jasa 
keuangan syariah. Maka dalam hal ini, pengembangan produk menjadi hal yang tak terhindarkan. Kemampuan untuk memberikan pelayanan perbankan syariah yang semakin beragam dengan tetap berpegang kepada prinsip kehati-hatian dan prinsip syariah khususnya melalui produk dan jasa bank menjadi salah satu dasar bagi keberlangsungan usaha bank syariah.

Dalam mengembangkan produk-produk barunya, bank syariah tidak boleh hanya mempertimbangkan tentang keuntungan yang akan diperoleh, akan tetapi juga harus memperhatikan dan mematuhi rambu-rambu syariah yang terdapat dalam fatwa DSN. Sebagaimana yang telah disinggung sebelumnya bahwa dalam pengembangan produk baru, DPS harus terlebih dahulu meminta penjelasan dari pejabat bank syariah yang berwenang mengenai tujuan, karakteristik, dan akad yang digunakan dalam produk baru tersebut. DPS selanjutnya akan melakukan pemeriksaan terhadap akad yang digunakan dalam produk terkait. Apabila akad yang digunakan dalam produk baru telah terdapat di dalam fatwa DSN, maka yang dilakukan DPS selanjutnya adalah menganalisis kesesuaian akad yang digunakan dalam produk baru dengan fatwa DSN. Jika sesuai, maka DPS akan memberikan opini terhadap kesesuaian syariah atas skim maupun prosedur yang terkait dengan produk baru tersebut, setelah itu barulah selanjutnya dimintakan izin pelaksanaannya kepada otoritas yang berwenang, yang dalam hal ini telah terjadi peralihan wewenang dari Bank Indonesia (BI) kepada Otoritas Jasa Keuangan (OJK).

3) Meminta fatwa kepada DSN MUI untuk produk baru bank yang belum ada fatwanya

Fungsi utama DSN MUI adalah mengawasi produk-produk lembaga keuangan syariah agar sesuai dengan syariah islam. Selain itu DSN juga berfungsi untuk meneliti dan memberi fatwa bagi produkproduk yang dikembangkan oleh bank syariah. (Antonio, 2001, hal. 32). Dalam pengembangan produk baru bank syariah, DPS harus memeriksa terlebih dahulu ada tidaknya fatwa DSN atas akad yang digunakan dalam produk baru tersebut, jika ternyata ditemukan bahwa akad yang digunakan belum ada fatwanya, maka DPS mengusulkan kepada direksi bank untuk melengkapi akad produk baru tersebut dengan fatwa DSN yang berlaku.

DSN MUI telah membuat pedoman untuk menetapkan sebuah fatwa atas pertanyaan maupun usulan produk bank syariah. (Umam, 2012, 
hal. 363). Berikut adalah alur penetapan fatwa atas sebuah pertanyaan atau usulan produk oleh DSN MUI:

a. Badan pelaksana harian menerima usulan atau pertanyaan hukum mengenai suatu produk lembaga keuangan syariah. Usulan ataupun pertanyaan ditujukan kepada sekretariat badan pelaksana harian

b. Sekretariat yang dipimpin oleh sekretaris paling lambat 1 (satu) hari kerja setelah menerima usulan atau pertanyaan harus menyampaikan permasalahan kepada ketua.

c. Ketua badan pelaksana harian bersama anggota dan staf ahli selambat-lambatnya 20 hari kerja harus membuat memorandum khusus yang berisi telaah dan pembahasan terhadap suatu pertanyaan atau usulan.

d. Ketua badan pelaksana harian selanjutnya membawa hasil pembahasan ke dalam rapat pleno DSN untuk mendapatkan pengesahan.

e. Fatwa atau memorandum DSN ditandatangani oleh ketua dan sekretaris DSN.

Singkatnya, mekanisme pengajuan fatwa produk baru bank syariah kepada DSN MUI dapat digambarkan sebagai berikut:

Gambar III. 1 Mekanisme Pengajuan Fatwa Kepada DSN MUI

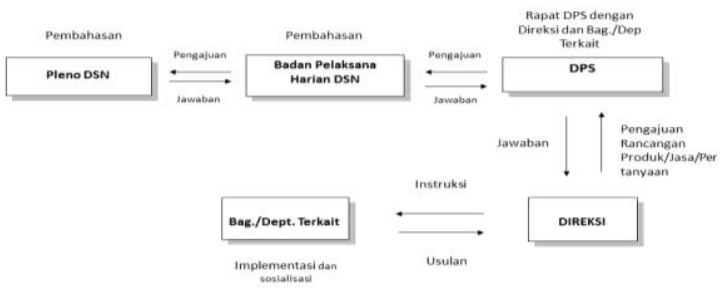

Sumber : (Antonio, 2001, hal. 32).

Disini penulis mencoba membahas sedikit terkait dengan masalah kinerja DPS yang sampai saat ini dinilai belum optimal dalam mengawal pemenuhan prinsip syariah dalam aktivitas perbankan syariah. Seperti yang telah dibahas sebelumnya bahwa salah satu dasar bagi keberlangsungan usaha bank syariah, terletak pada kemampuannya dalam memenuhi berbagai kebutuhan pelayanan jasa keuangan syariah, otomatis variasi produk menjadi hal yang tidak bisa dihindari. Dalam rangka pengembangan produk baru, bank syariah tentu saja harus tetap 
berpegang teguh pada pemenuhan prinsip syariah yang terdapat di dalam fatwa DSN. Sementara, dari penjelasan sebelumnya dapat diketahui bahwa DSN lebih banyak menunggu pertanyaan atau pengajuan usulan, sehingga konsekuensinya fatwa di keluarkan hanya jika ada pihak yang menanyakannya, bukan atas inisiatif dan gagasan DSN.

Lambatnya DSN dalam merespon kebutuhan-kebutuhan akan fatwa terhadap pertanyaan atau usulan produk menyebabkan pihak manajemen melakukan inisiatif bisnis selama DPS mengizinkan, sedangkan disisi lain, Bank Indonesia dalam melakukan pemeriksaan selalu hitam putih artinya selama tidak diatur oleh fatwa maka apa yang dilakukan oleh manajemen bank syariah adalah haram.

Dari paparan dia atas dapat disimpulkan bahwa DPS adalah ujung tombak dalam masalah pengawasan kepatuhan bank syariah, oleh karena itu, penting bagi seorang anggota DPS untuk memiliki kualifikasi keilmuan yang integral antara ilmu fiqih muamlah dan ilmu ekonomi keuangan islam modern. Kesalahan yang terjadi di perbankan syariah saat ini adalah pengangkatan DPS bukan berdasarkan pada keilmuannya, maka sudah bisa dipastikan bahwa fungsi pengawasan DPS tidak akan optimal. Akibatnya, penyimpangan dalam praktek syariah menjadi hal yang mungkin dan sering terjadi.

4) Melakukan review secara berkala atas pemenuhan prinsip syariah terhadap mekanisme penghimpunan dana dan penyaluran dana serta pelayanan jasa bank

Dalam hal kegiatan penghimpunan dana dan penyaluran dana serta pelayanan jasa, bank syariah wajib untuk memenuhi prinsip syariah, sebagaimana yang diatur dalam PBI No. 10/16/PBI/2008 tentang perubahan atas PBI No. 9/19/PBI/2007 tentang pelaksanaan prinsip syariah dalam kegiatan penghimpunan dana dan penyaluran dana serta pelayanan jasa bank syariah.

Hal ini dapat terlihat dari akad-akad yang digunakan dalam produk-produk penghimpunan dana, penyaluran dana, serta pelayanan jasa bank syariah yang dilaksanakan dengan prinsip-prinsip keadilan dan keseimbangan ('adl wa tawazun), Kemaslahatan (maslahah), universalisme (alamiyah) serta tidak mengandung gharar, maysir, riba, dzalim, riswah, dan objek haram.

DPS harus memastikan bahwa produk penghimpunan dana, penyaluran dana serta pelayanan jasa bank syariah telah sesuai dengan fatwa DSN dan telah memperoleh opini DPS bank yang bersangkutan serta telah memperoleh persetujuan dari otoritas perbankan syariah. 
Review secara berkala terhadap mekanisme penghimpunan dana, penyaluran dana, dan pelayanan jasa perbankan dapat dilakukan melalui :

1. DPS melakukan sinergi dengan pelaksana fungsi audit bank syariah untuk melakukan proses audit (termasuk aspek syariah) terhadap seluruh kegiatan perbankan meliputi mekanisme penghimpunan dana, penyaluran dana, serta pelayann jasa perbankan.

2. DPS juga melakukan kegiatan review terhadap pelaksanaan produk yang dimiliki bank syariah, baik dalam kegiatan penghimpunan dana, penyaluran dana, serta pelayanan jasa bank syariah dengan tujuan untuk mengetahui pemenuhan prinsip syariah pada pelaksanaan operasional bank syariah. Kegiatan review dilakukan oleh DPS pada divisi pada unit kerja lainnya.

3. DPS juga dapat melakukan uji petik (sampel) untuk memeriksa dokumen transaksi bank syariah untuk mengetahui pemenuhan prinsip syariah sebagaimana dipersyaratkan dalam SOP, antara lain:

a. Pemenuhan syarat dan rukun dalam akad pembiayaan maupun akad penghimpunan dana antara bank syariah dengan nasabah.

b. Ada tidaknya bukti pembelian barang untuk akad murabahah sebagai bukti terpenuhinya syarat jual beli murabahah.

c. Ada tidaknya laporan usaha nasabah, untuk akad mudharabah dan/ atau musyarakah, sebagai dasar melakukan perhitungan distribusi bagi hasil.

Keseluruhan temuan hasil uji petik (sampel), selanjutnya disampaikan kepada direksi atau unit kerja terkait untuk ditindak lanjuti dan diperbaiki guna memenuhi kesesuaian dengan prinsip syariah yang telah ditetapkan.

5) Meminta data dan informasi terkait dengan aspek syariah dari satuan kinerja bank dalam pelaksanaan tugasnya

Dewan pengawas syariah terlibat aktif dalam proses pengawasan aspek syariah pada setiap lini kegiatan yang menjadi tugas dan tanggungjawabnya. Semua kegiatan yang dilaksanakan oleh DPS tentu memerlukan data dan informasi yang akurat dari satuan kerja atau unit kerja terkait. Kesadaran akan pentingnya pemenuhan aspek syariah oleh semua satuan kerja atau unit kerja di bank syariah dapat mendukung pelaksanaan tugas DPS. Dalam menjalankan tugas pengawasannya DPS dapat bersinergi dengan baik dengan satuan kerja atau unit kerja di bank 
syariah sehingga seluruh kebutuhan data dan informasi yang dibutuhkan oleh DPS dapat terpenuhi. Data dan informasi yang dibutuhkan DPS dalam rangka melaksanakan tugas dan pengawasannya dapat diperoleh melalui kegiatan diskusi, dokumen kerja, data transaksi, rislah rapat, dan lain-lain.

Misalnya DPS hendak memeriksa bagaimana perlakuan bank syariah atas pencatatan dan pengakuan pendapatan yang berasal dari pengenaan denda, penempatan pada bank konvensional, dan pendapatan non halal lainnya atau pencatatan dan pelaporan penerimaan dana dari zakat, infak dan sedekah (ZIS), maka bank syariah harus memberikan kesempatan kepada DPS untuk mengakses seluruh dokumen, data, dan informasi kegiatan usaha bank termasuk dari konsultan dan pegawai bank syariah untuk memperkuat hasil pemeriksaan DPS.

\subsection{Pelaksanaan Tugas Dan Tanggung Jawab DPS Dalam Rangka Pelaporan}

Terkait dengan tanggung jawab DPS dalam rangka pelaporan, DPS mempunyai tanggung jawab untuk menjalankan fungsi pelaporan hasil pengawasannya pada hal-hal sebagai berikut:

1) Menyampaikan laporan hasil pengawasan DPS secara semesteran kepada Direksi dan Komisaris.

Dewan pengawas syariah melaporkan hasil pengawasannya kepada direksi dan dewan komisaris sebanyak 2 (dua) kali dalam setahun.

2) Dewan pengawas syariah juga menyampaikan laporan hasil pengawasannya kepada OJK dan DSN MUI yang memuat hasil pelaksanaan tugas dan tanggung jawab DPS selama semester I dan II setiap tahunnya, meliputi:

a. Kertas kerja pengawasan terhadap proses pengembangan produk baru bank syariah.

b. Kertas kerja pengawasan terhadap kegiatan operasional bank syariah.

3) Laporan hasil pengawasan DPS berisikan pendapat kepatuhan (compliance opinion) dan atau adanya pelanggaran (violations opinion) kegiatan usaha bank syariah dalam pelaksanaan akad, transaksi, alokasi bagi hasil atau sumber pendapatan atau sumber dan penggunaan dana ZIS terhadap prinsip syariah. laporan DPS harus ditandatangani oleh seluruh anggota DPS, diterbitkan secara tahunan serta harus dipublikasikan bersamaan dengan penerbitan laporan tahunan bank syariah. 
Demikianlah penjelasan mengenai bagaimana peran dewan pengawas syariah (DPS) dalam pemenuhan prinsip syariah dalam pelaksanaan good corporate governance (GCG) pada perbankan syariah. Peraturan Bank Indonesia No. 11/33/PBI/2009 telah memberikan tugas dan tanggung jawab yang sangat rinci kepada DPS terkait dengan pelaksanaan GCG di perbankan syariah yang bertujuan untuk mewujudkan perbankan syariah yang tangguh dan unggul.

Dari paparan di atas, mengenai tugas dan tanggung jawab DPS yang tertera dalam Peraturan Bank Indonesia No. 11/33/PBI/2009 dapat disimpulkan bahwa dalam pelaksanaan tugas dan tanggung jawabnya, DPS telah berupaya untuk mencerminkan pelaksanaan 5 (lima) prinsip dasar GCG. Dari prinsip keadilan, setiap keputusan yang diambil DPS senantiasa memperhatikan dan melindungi kepentingan para stakeholders. Sebagai bagian dari perangkat pelaksanaan GCG di perbankan syariah, DPS juga memenuhi prinsip keterbukaan dengan mencantumkan segala aktivitas pengawasannya dalam laporan GCG. Dalam melaksanakan tugasnya mengawasi pemenuhan prinsip syariah, tentusaja DPS harus bertanggungjawab dalam memastikan kesesuaian operasional bank dengan prinsip syariah dan aturan lainnya yang berlaku. Dari segi prinsip akuntabilitas, diwujudkan dengan adanya kejelasan fungsi dan pertanggungjawaban DPS sehingga dalam melaksanakan kegiatannya dapat berjalan secara efektif. Dan terakhir, prinsip profesional terwujud dari pengankatan DPS yang memiliki kompetensi, mampu bertindak objektif dan bebas dari pengaruh atau tekanan pihak manapun (independen) serta memiliki komitmen yang tinggi untuk mengembangkan bank syariah.

Terakhir, meskipun tidak bisa dipungkiri bahwa aktivitas pengawasan kepatuhan syariah yang dilakukan oleh DPS pada kondisi dilapangannya belum dapat dilakukan secara optimal, diharapkan, melalui apa yang telah diatur dalam PBI No. 11/33/PBI/2009, dimana tugas dan tanggung jawab DPS telah dirinci dengan jelas, DPS dapat terus memperbaiki kinerjanya. kunci selanjutnya dalam pengawasan pemenuhan pemenuhan prinsip syariah pada perbankan syariah tergantung pada bagaimana komitmen DPS, bank syariah, DSN dan OJK untuk saling bersinergi demi mewujudkan bank syariah yang memiliki tata kelola yang baik dengan tingkat kepatuhan pada prinsip syariah yang tinggi. 


\section{PENUTUP}

Dilihat dari analisa dan pembahasan yang telah diuraikan pada bab sebelumnya, penulis dapat menyimpulkan bahwa Good corporate governance (GCG) pada perbankan syariah yang diatur dalam PBI No. 11/33/PBI/2009 tentang pelaksanaan good corporate governance bagi bank umum syariah dan unit usaha syariah merupakan suatu tata kelola bank syariah yang menerapkan prinsip-prinsip keterbukaan (transparancy), akuntabilitas (accountability), profesional (professional), pertanggungjawaban (responsibility), dan kewajaran (fairnes). Pelaksanaan GCG pada perbankan syariah juga harus memenuhi kepatuhan terhadap prinsip syariah yang tercermin dengan adanya pelaksanaan tugas dan tanggung jawab dewan pengawas syariah (DPS). DPS yang keberadaannya wajib dimiliki oleh setiap perbankan syariah mempunyai peran yang sangat penting yaitu memastikan semua produk dan prosedur perbankan syariah telah memenuhi prinsip syariah. Hal ini merupakan aspek yang terpenting dalam perbankan syariah karena menyangkut reputasi perbankan syariah dimata masyarakat sebagai cermin bank yang benar-benar telah memenuhi prinsip syariah (islami) dalam aktivitasnya. Pelaksanaan tugas dan tanggung jawab DPS dalam pemenuhan prinsip syariah dalam pelaksanaan GCG di bank syariah, terwujud dalam 3 (tiga) fungsi, yaitu: fungsi koordinasi, fungsi pengawasan dan fungsi pelaporan.

\section{DAFTAR PUSTAKA}

Undang Undang No. 21 Tahun 2008 Tentang Perbankan Syariah. (2008). Agustianto. (2011, April Sabtu). Agustianto. Dipetik Juni 10, 2014, dari www.agustiantocentre.com: www.agustiantocentre.com/?p=333

Ali, Z. (2007). Hukum Perbankan Syariah. Jakarta: Sinar Grafika.

ALQur'an. (2005). ALQur'an dan Terjemahan Departemen Agama RI. Depok: Al Huda.

Amin, M. (2007). Prospek Cerah Perbankan Syariah. Jakarta: Lekas.

Antonio, M. S.(2001).Bank Syariah : Dari Teori Ke Praktik. Jakarta: GIP.

Badan Pusat Statistik. (2010). Badan Pusat Statistik. Dipetik Juli Kamis, 2014, dari Badan Pusat Statistik: http://sp2010.bps.go.id

Bank BNI Syariah. (2013). Laporan Pelaksanaan GCG Bank BNI Syariah Tahun 2013. Jakarta: Bank BNI Syariah.

Bank Indonesia. (2008). Peraturan Bank Indonesia No. 10/16/PBI/2008 tentang pelaksanaan Prinsip Syariah Dalam Kegiatan 
Penghimpunan Dana Dan Penyaluran Dana Serta Pelayanan Jasa Bank Syariah. Jakarta: BI.

Bank Indonesia. (2009). Peraturan Bank Indonesia No. 11/3/PBI/2009 Tentang Bank Umum Syariah. Jakarta: BI.

Bank Indonesia. (2009). Peraturan Bank Indonesia No. 11/33/PBI/2009 Tentang Pelaksanaan Good Corporate Governance bagi Bank Umum Syariah dan Unit usaha Syariah. Jakarta: Bank Indonesia.

Bank Muamalat. (2013). Laporan Pelaksanaan GCG Bank Muamalat Tahun 2013. Jakarta: Bank Muamalat.

Bank Syariah Mandiri. (2013). Laporan Pelaksanaan GCG Bank Syariah Mandiri Tahun 2013. Jakarta: Bank Syariah Mandiri.

Direktorat Perbankan Syariah. (2013). Statistik Perbankan Syariah. Jakarta: Bank Indonesia.

Faozan, A. (2013). Implementasi Good Corporate Governance Dan Peran Dewan Pengawas Syariah Di Bank Syariah. La Riba, 9-10.

Ibrahim, J. (2005). Teori dan Metode Penelitian Hukum. Malang: Bayu Media Publishing.

Madjid, M. N. (2011). Nuansa Konvensional Dalam Perbankan Syariah. Nalar Fiqih, 5.

Muhammad. (2011). Audit dan Pengawasan Syariah Pada Bank Syariah. Yogyakarya: UII Press.

Rachmat, R. P. (2013). Pertanggungjawaban Dewan Pengawas Syariah (DPS) Atas Kerugian Bank Syariah Dalam Tinjauan Hukum Korporasi. Researchgate.

Rochman, A. S. (2008). Tinjauan Perbandingan Pidana Perampasan Kemerdekaan Berdasarkan Kajian Berbagai KUHP Asing. Semarang: Eprintis Undip.

Santoso, B. (2012, September Rabu). BI Temukan Bank Syariah yang Langgar Prosedur Gadai Emas. Dipetik Agustus Minggu, 2014, dari m.sorotnews.com

Sari, M. D., Bahari, Z., \& Hamat, Z. (2013). Perkembangan Perbankan Syariah Di Indonesia. Jurnal Aplikasi Bisnis, 123.

SEBI. (2013/2014). Panduan Penyusunan Skripsi. Jakarta: STEI SEBI.

Soejono, \& Abdurrahman. (2003). Metode Penelitian Hukum. Jakarta: Rineka Cipta.

Soekanto, S. (1990). Metode Penelitian Hukum. Jakarta: Rajawali Pers.

Sunggono, B. (2010). Metode Penelitian Hukum. Jakarta: Raja Grafindo Persada Pers.

Susanto, B. (2008). Hukum Perbankan Syariah di Indonesia. Yogyakarta: UII Press.

Sutedi, A. (2009). Perbankan Syariah : Tinjauan dan Beberapa Segi Hukum. Jakarta: Ghalia Indonesia.

Tunggal, A.W. (2007). corporate governance (suatu pengantar). Harvarindo 
Umam, K. (2012). Legislasi Fikih Ekonomi Perbankan : Sinkronisasi Peran Dewan Syariah Nasional dan Komite Perbankan Syariah. Mimbar Hukum, 363.

Wardayati, S. M. (2011). Implikasi Shariah Governance Terhadap Reputasi dan Kepercayaan Bank Syariah. Walisongo, 9. 